\title{
QUESTIONS TO HELP UNDERSTAND RELIGION AND DEVELOPMENT IN VANUATU
}

\author{
Matthew Clarke ${ }^{1}$
}

\begin{abstract}
Across the Pacific, Christianity features prominently in both the modern history as well as the contemporary social-political experiences of these countries. In Vanuatu, self-professed Christian religious belief approaches one hundred per cent of the population. It is clear that religion in Vanuatu has important effects on development processes, social services, institutions, and social networks. Yet, despite this self-evident close integration, much more research is required to better understand the entanglements of Christianity and development. Drawing on previous research in Vanuatu, this article identifies seven key questions that require further research. These questions cover issues associated with gender, participation, leadership, theology, partnerships, and dynamics of religious change. It is proposed that these seven questions also have relevancy across the Pacific region. Holding greater knowledge of the intersection between religion and development will lead to more authentic engagement with religion and religious organisations and potentially better development outcomes for local communities.
\end{abstract}

Keywords: Christianity; development; Vanuatu; Pacific Islands

\section{INTRODUCTION}

Vanuatu, previously known as New Hebrides, is an archipelago within the South Pacific that is spread across 1300 kilometres. Despite a relatively small population approaching around 290,000 people, it is estimated that over one hundred languages are spoken across the nation (Crowley 2005; Mitchell 2004). Eighty per cent of the population lives in rural communities. The capital Port Vila is the largest urban centre with a population of around 50,000, followed by Luganville with a population of around 10,000. Using a Multidimensional Poverty Index (MDPI), it is clear there are high levels of deprivation in certain 
population cohorts within Vanuatu (Clarke et al. 2014). The incidence of multidimensional poverty is highest in the capital Port Vila (Efate) with twenty-eight per cent of households living in multidimensional poverty, and Baravet (Pentecost) with sixteen per cent (Clarke et al. 2014). Moreover, forty-two per cent of Vanuatu households also face deprivation in one or more areas of health, education, economic security, and access to social services. Thus, half of Vanuatu's population either live in poverty or are at risk of living in poverty. According to the Asia Development Bank (2005), improving well-being in Vanuatu (and across Melanesia) is difficult given its: 1) remoteness; 2) susceptibility to natural disasters; 3) low institutional capacity; 4) limited diversification of economic activity; and 5) poor access to capital and investment.

It is imperative therefore that due consideration be given to improving the material well-being experienced in Vanuatu. A focus on achieving positive development outcomes should be the priority of national and provincial governments, domestic and international non-government organisations, and civil society organisations. Within Vanuatu, the Christian churches are a cornerstone of civil society and therefore must play a central role in any effort to sustain and extend well-being. This article outlines seven questions about the intersection of Christianity and development in Vanuatu, including concerning issues of gender, participation, leadership, theology, partnerships, and the changing roles of religion. Holding greater knowledge of the intersection between religion and development will lead to more authentic engagement with religion and religious organisations and potentially better development outcomes for local communities which is necessary to enhance efforts to improve the lives of those in Vanuatu who are most vulnerable to poverty. It is argued these questions have broader relevance across the Pacific region as countries in this region do share common (though not identical) experiences of mission, colonialisation, political independence, and constraints on development.

Over the past decade, I have been involved in four significant research projects into development processes in the Pacific, each focusing on Vanuatu. These projects have examined questions of national identity, aid effectiveness, economic vulnerability and resilience, and children with disabilities. My experience of conducting research in Vanuatu has convinced me that development in the Pacific is inextricably entangled with Christianity. Christian churches are ubiquitous throughout the more than eighty islands that comprise the nation of Vanuatu and their work in social services, including education and health, as well as community development, is far-ranging. Christianity also has a significant influence on politics and wider social issues, including playing significant roles in shaping gender relations and ethnicity. However, and unfortunately, 
far too little research to date has examined the roles, locations, and influences of Christianity on development processes in Vanuatu. This is not unique to Vanuatu of course, with the situation being much the same across the Pacific.

\section{RELIGION AND DEVELOPMENT}

Religion is increasingly gaining prominence within the development sector and more recent literature is indicating that the relationship between religion and development is an issue that requires greater consideration and understanding (see Clarke 2011; 2013; Deneulin and Bano 2009; ter Haar 2011; Rees 2011; Fountain et al. 2015; Tomalin 2015). This recognition is relatively recent, with religion historically being invisible (at best) or taboo (at worst). Within the traditional discourse there were three primary approaches to the question of 'religion'. The first was that religion was private and so the appropriate response from the development perspective was that it should be largely ignored. The second approach was that religion could be subsumed under the mantle of 'culture' and along with other cultural practices and beliefs, its external expression and networks should be appropriated if that would further the goals of development. The final approach to understanding religion within the traditional development paradigm was that religion was actually a bottleneck to modernisation, whereby religious beliefs actively constrained economic and social relationships and limited the ability of economies to transform. The response considered appropriate was to actively promote modernisation and exclude religious leaders and networks. Common to all these three approaches was the firm expectation that once the fruits of development and process of modernisation became increasing evident, the effect of religious belief and practice would weaken and withdraw from the public sphere.

These approaches failed to consider the private and public impact of religious belief and practices. Religious belief plays an important role in aiding an individual to conceive and understand their own worldview. Sacred texts and religious teaching provide information that informs people in determining how they understand their own personal circumstances and may temper their own response within this context. Religion also may have public influence beyond that envisaged within the traditional development paradigm. Religious beliefs and practices can shape and drive social norms, social structures, public policies, and laws as well as shape advocacy activities. Such events do not occur in a moral vacuum and in communities where religious belief and practice is common, this influence can be strong. As Goulet $(1980,485)$ noted: 
[religious beliefs] ... harbour within them a latent dynamism which, when properly respected, can serve as the springboard for modes of development which are more humane than those drawn from outside paradigms. When development builds from indigenous values it extracts lower social costs and imposes less human suffering and cultural destruction then when it copies outside models. This is so because indigenously-rooted values are the matrix whence people derive meaning in their lives, a sense of identity and cultural integrity, and the experience of continuity with their environment and their past even in the midst of change.

While religion is by no means a panacea to development issues and can actively work to worsen development outcomes through tendencies towards hierarchical structures, gender imbalances, fatalism, and so forth ${ }^{2}$ (Fox and Sadler 2006; Seiple and Hoover 2004), it can have a positive impact that deserves further scrutiny and appreciation. Increasing religious literacy of those seeking to be involved in development interventions is a key aspect of this. Religious literacy provides an opportunity for authentic engagement between those working within the development sector and seeking to effect positive change and the communities with whom they work and for whom this change is aimed. Religious literacy opens up opportunities for dialogue by providing for clearer understandings of the world view of those holding religious beliefs. It allows greater clarity around points of similarity between different religious belief systems but also highlights points of tension. Both are necessary if stronger communication based on a more genuine appreciation of these differences is to occur. By being able to speak more confidently and candidly about the religious beliefs that shape world views and private behaviours, there is more likelihood of connections being made between parties. It is also more likely to reduce instances of misunderstandings or embarrassment when working with communities, institutions, or individuals holding religious beliefs. This literacy should at its least include greater knowledge of sacred texts and social teachings of the particular religion, as well an in-depth understanding of the cultural context within which these religious beleifs are located. Given the near universal adherence to Christianity within Vanuatu, and across the Pacific more generally, poor religious literacy of Christianity by those within the development sector will limit the achievement of optimal development outcomes.

This literacy should not simply be limited to theological appreciation of religious beliefs and teachings but also include knowledge of religious practices, rituals, institutional structures, and key leaders. To be more effective, religious literacy should also include consideration of the historical and contemporary 
impact religion has had and continues to have in communities. This contextual understanding is important to place religion into the broader appreciation of how the community functions, but also may provide greater appreciation of the role and impact religious institutions and individuals have within that community.

\section{CHRISTIANITY AND DEVELOPMENT IN VANUATU}

Vanuatu can be considered one of the world's most religious countries. While the most recent census (Vanuatu National Statistics Office 2009) headline figure for Christian affiliation is eighty-three per cent, the actual proportion of the population self-identifying as Christian is closer to ninety-six per cent. ${ }^{3}$ This pervasive religious belief is a direct result of the missionary encounter with $\mathrm{Ni}$-Vanuatu, starting with the London Missionary Society which first arrived in 1839. ${ }^{4}$ Further Presbyterian and Anglican missions followed a decade later. Over the course of the next one hundred years, new waves of missionaries arrived and began working across the whole of the archipelago. These included French-speaking Catholic missionaries in 1887, Churches of Christ in 1901, Seventh Day Adventists in 1912 and the Apostolic Church in 1946. Two of the defining characteristics of the missionary experience across Vanuatu over this period were the heavy focus by all the missions on the provision of health and education services (Hilliard 1978) as well as ceding leadership of the churches to local members (Brown 2009). Indeed, despite the dual colonial presence of both the French and the British, these welfare services were predominately provided by the churches rather than the state up until the last few years before Independence in 1980 (Miles 1998; Woodward 2014). ${ }^{5}$ A clear example of these missions seeking local leadership was the use of local language for the 1921 General Synod of the Presbyterian Church.

While there had been ad hoc European contact from the start of the seventeenth century, there was no sustained contact until the mid-nineteenth century with the arrival of these missionaries occurring alongside the arrival of European merchants and settlers seeking commercial opportunities. The majority of Europeans in Vanuatu in the later part of the nineteenth century were French and British citizens (with the majority of these British citizens being Australianborn). Operating without legal constraints (or protection), there is a significant history of people and resources being removed from Vanuatu for commercial gain. Recognising the need to provide some certainty to its citizens, the French and British governments declared New Hebrides a neutral territory in 1878 , but in the absence of any colonial presence, there was increasing pressure from these settlers for more direct oversight. Thus, in 1887 a Joint Naval Commission 
was established which was eventually expanded to become a more permanent administrative presence known as the British-French Condominium. As a result, formal colonial rule over New Hebrides was jointly held by both the French and the British with concurrent legal systems. Of course, none of these endeavours were established for the betterment of the Ni-Vanuatu population who were largely ignored by these colonial authorities, leaving the churches to continue providing the only functioning health and education systems across the country.

Within this social services vacuum, the churches became increasingly relevant nationally, and whilst denominations had certain spheres of dominance due to the original location of their founding missionaries, the institutional structures of the larger churches were found the breadth and width of the country. As a result, church leaders became de-facto national leaders and it was from within this cadre of Ni-Vanuatu religious leaders that the call for political independence was initiated, built, and finally achieved.

Vanuatu's Independence in 1980 was largely a result of local church leaders first proclaiming, and then campaigning for political freedom utilising the national platforms of their various denominations. Indeed, given the limited French and British colonial state apparatuses that were operating, there were no other domestic structures in which local leaders could gain the skills, expertise, education, and experience required to seek and achieve independence. As the various churches had country-wide networks, and were co-ordinating education systems and health care, as well as providing other social services throughout the nation, local church leaders were exposed to opportunities that were not available to them outside their churches.

Drawing on these experiences and opportunities, church leaders began to agitate for independence in the early 1970s. Indeed, the Presbyterian Church was the first entity in Vanuatu to call for Independence, as it did at its General Synod in 1973. From this point onwards, church leaders began to form political parties to further the cause of independence. These early political parties, set up by church leaders, used church buildings as locations in which to meet when such political gatherings were deemed by the colonial authorities as illegal.

Having provided the overwhelming majority of health, educational, and other social services, as well as its social and political leadership for the last century, the churches across Vanuatu have continued to be very prominent in these areas, and more recently, are now involved in the provision of development and humanitarian responses (Clarke and Halafoff 2017). This active role gives 
rise to a range of queries that need to be understood in order to ensure optimal development outcomes within Vanuatu. As such, the remainder of this article sets out a range of issues that should be better understood by those seeking to address the social, political, and economic development of Vanuatu. These questions draw on recent research undertaken across Vanuatu and Melanesia, covering issues associated with gender, participation, leadership, theology, partnerships, and the on-going relevance of religion. It is proposed that these seven questions also have relevancy across the broader Pacific region. With the exception of Papua New Guinea, island states in the Pacific, including Vanuatu, typically have very small populations. As such, nation case studies from this region might seem very specific with little relevance to other (larger) nations. However, in the case of Vanuatu, it is precisely its size and relative religious homogeneity that makes it worthwhile to further investigate. By considering Vanuatu, with limited religious distinctions and strong co-operation across denominations, it is possible to more clearly identify the role that religion and religious beliefs and institutions can have on the social, political, and economic development experiences. This knowledge can then be tested in other settings under different circumstances. Moreover, there are sufficient similarities in terms of missionary and colonial history as well as the contemporary role of churches within other small island Pacific states to make the questions highlighted below relevant to the region more generally. With minor editing, each question below could be reasonably asked of any number of Pacific nations.

\section{What are the church backgrounds of current Ni-Vanuatu political leaders?}

The Condominium powers of France and Britain that jointly held responsibility for Vanuatu from 1906 to its independence in 1980, failed to properly provide social services (including health and education) across the entire country. As the various churches had been providing these services for decades prior to the arrival of France and Britain, they continued to do so under colonial government. As a result, the Anglican, Catholic, Pentecostal, and evangelical denominations have played a very important role in the political and social development of Vanuatu.

The churches in Vanuatu provided four important opportunities to local leaders that facilitated the Independence movement within this region:

- higher education;

- national leadership roles;

- countrywide networks; and

- international higher education study. 
For example, when Sethy Regenvanu became the first Deputy Prime Minister following Independence in 1980, he did so having lived nearly his entire life within the institutions of the Presbyterian Church. He attended the local church primary school before being selected to attend the regional church secondary school. He spent twelve months on a church-sponsored youth-leadership programme in Papua New Guinea, before undertaking formal theological studies in Fiji. Upon completion of all this study, his first significant paid position was within the education office of the Presbyterian Church. Through these experiences, and in his own words, he 'acquired a new vision of the future of Vanuatu' (Regenvanu 2004, 57). This vision included an independent and economically prosperous Vanuatu. Regenvanu's experience was not unique. Without the Christian churches, Vanuatu 'would not have had the handful of educated indigenous people at the crucial stage to direct the country in its course towards political Independence' (Regenvanu 2004, 170). These included ordained Anglican priests Fr. Walter Lini and Fr. John Bani; Presbyterian pastors Sethy Regenvanu, Willie Korisa, Jack Hopa, Jack Taritonga; Presbyterian elders George Sokomanu, Thomas Reuban, and John Naupa; Church of Christ pastor Samuel Bul; and Roman Catholic priest Fr. Gerard Leymang.

The political leaders were church leaders in the first instance and it was their church leadership that shaped their approach to secular political leadership. For those seeking to engage with the current cohort of Vanuatu's political leadership, better knowledge of their previous leadership roles would be beneficial. Do the current political leaders of Vanuatu have previous church leadership backgrounds or did they gain their leadership opportunities through other avenues?

2. What role does gender play formally and informally in church leadership (and how does this affect political discourse in Vanuatu)?

Given the preponderance of men involved in contemporary church leadership in Vanuatu, it is also important to pay attention to questions of gender. Such an analysis must include the impact of early missionary attitudes to gender. Douglas (2002) highlights the lack of agency afforded to women by early missionaries and the the normative practice of placing men in leadership positions. While men were given public responsibilities, women were called to express their Christian fellowship through working collectively on more domestic tasks (see Mate 2002 for similar experiences in Africa). ${ }^{6}$ As a result, women were excluded from the formal leadership within churches.

However, a focus on collective fellowship led directly to the establishment of sub-church groups to serve this need, which in turn led to alternative leadership 
opportunities. The Presbyterian Missionary Women's Union (PMWU) is part of the Presbyterian Church but is organised and structured as a separate entity. It currently has close to 8000 members across the country. The PMWU was formed in 1945 by two Australian missionaries, Amy Skinner and Kath Ritchie (Massam 2015). Both women provided maternal and child health care as nurses on the island of Ifira (which sits opposite the main town of Vila). In the course of their medical work, both Skinner and Ritchie became keenly aware of the wider needs of these mothers and their children and families. Understanding the constraints on women in traditional Vanuatu communities, Skinner and Ritchie set about establishing a fellowship program that local women would be allowed to attend. At this time, Ni-Vanuatu women enjoyed limited freedom. Culturally they stayed home to tend the gardens, prepare food, and raise children. At this time, women were not free to decide where to go or whom to visit. Understanding this, Skinner and Ritchie established the PMWU to initially provide fellowship opportunities for women. Because the PMWU was a religious organisation, governed under the auspices of the Presbyterian Church, husbands and fathers allowed women to join this fellowship and participate in an array of activities that was not previously possible for women. The PMWU has four guiding principles that today drive its work. These principles are known as the ${ }_{4} \mathrm{Ss}$ : spirituality, service, social, and study. As a result, members of the PMWU undertake a range of socially engaged activities in addition to worship that enhance their local communities.

The PMWU is a powerful illustration of the role women play in religious and social spheres in Vanuatu. Are similar opportunities replicated in other denominations across the country? Have women in Vanuatu been able to parlay their important leadership in the PMWU and other churches into other more formal political roles or have they been able to generate political pressure through other networks or positions?

\section{Is there still a distinct Vanuatu theology of development/independence?}

The call for Independence was first publicly made from the lectern in the Paton Memorial Presbyterian Church in Port Vila in 1973, and was deeply informed by liberation theology. Early Independence (and church) leaders were exposed to this theology during their periods of study and work across the Pacific. This theology was adapted to the Vanuatu experience and informed both the Independence movement and also the development planning that soon followed (Regenvanu 2004; Lini 1982). Yet, despite Independence being achieved in 1980, Vanuatu still experiences low levels of development (Clarke et al. 2014). 
As Vanuatu approaches its fortieth year of Independence, the need remains to increase the well-being of its population. What is the current motivation or driver for this development? Does it still contain a theological basis or is the current driver for development understood largely in secular terms? For example, the Vanuatu Christian Council led national protests again Vanuatu joining the World Trade Organization, though they were unsuccessful in this campaign. What was the theological basis for this opposition? What alternative paths to development do the churches prefer and promote?

\section{What are the wider attitudes to Christian identity and national identity?}

The attitudes of young tertiary students across Vanuatu provide useful insights into how that specific demographic understand their own identity and the importance of Christianity in identifying someone as Ni-Vanuatu. These young people are amongst the most highly educated of their cohort and typically lived away from their home island and community for part of their education experience. According to a survey discussed by Leach et al. (2013), tertiary students believed that being respectful of traditions and customs, respecting institutions and laws, 'feeling Ni-Vanuatu', and being a Christian were all strongly important in identifying as a Ni-Vanuatu, with each being ranked by around eighty per cent of respondents. Interestingly, these responses were based on language divisions that indicated shifting priorities. Anglophones reported being Christian as important for being 'truly Ni-Vanuatu' much more highly than Francophones - twenty per cent more Anglophone respondents ranked it as being very important (eighty-six per cent compared to sixty-six per cent). With one third of the Vanuatu Francophone, this language divide may indicate a significant fault-line across the country.

Is it reasonable to suggest that the views of these future elites who have experienced the relatively limited opportunity of tertiary education are shared across the wider population? Is 'being Christian' an important pre-requisite for someone to be Ni-Vanuatu for community members with different educational levels, from different age cohorts, or from different primary language backgrounds?

\section{How do Ni-Vanuatu experience their daily Christian engagement?}

With near universal self-reporting Christian faith in Vanuatu, it might reasonably be expected that there would be a high level of attention paid to the tenets of this faith and participation in religious services across the country. There is a difference, however, between self-reporting religious belief and actively attending religious services. Anecdotal evidence suggests church-going in Va- 
nuatu is a gendered phenomenon, with women making up the bulk of weekly congregations. A gendered religious attendance profile has been noted across a range of countries, including Australia, Britain, UsA, Philippines, and France (Singleton 2014). ${ }^{7}$ A clearer understanding of participation (attendance) rates at church services by gender and age and denomination could assist development agencies access community members. As Clarke and Halafoff (2017) have demonstrated, sacred places (such as church buildings) play a central role as development spaces across humanitarian emergencies, water and sanitation training, gender training, and so forth. Within these sacred buildings community development interventions can be highly effective. Therefore, understanding who is using these buildings and when and for what purposes will aid planning and partnerships between local communities and agencies.

Having been born, raised, and educated in the church since Independence, the relevancy of Christianity to young people is of interest as they will shape Vanuatu's future. As discussed above, young elites noted that being Christian is an 'important' part of being Ni-Vanuatu, and that 'Christianity helps bring people together', but it is not clear whether this trend continues outside of those who have received tertiary education. Whether religiosity has 'stuck' with this wider second post-Independence generation remains unclear. This is important as declining religious attendance does not necessarily proceed in a linear fashion, but may follow wave patterns involving episodic decreases in those self-professing religious belief (Singleton 2014). While there is no good reason to presume that Vanuatu will follow Western secularisation patterns, it should also not be presumed that Christianity will remain overwhelmingly popular into the future.

Investigating the religious beliefs of younger people in greater detail would assist in gaining a more complete understanding of how to assess this specific and important demographic, and also possible shifts in the value of religion in economic, social, and political development across Vanuatu in the coming years.

\section{How do Christian churches manage partnerships with secular aid agencies or non-Christian faith-based organisations (FBOs)?}

Due to their country-wide networks and deep organic connections with local communities, a recognised strength of the churches in Vanuatu is their ability to access remote or small communities that national or provincial governments have difficulty accessing. Aid agencies are also attracted to working with churches for this reason. The partnerships between these aid agencies and various churches in Vanuatu are based on recognising the complementarity 
that the different groups bring in terms of access to communities with sectoral expertise and funding.

Certain churches have recently been able to expand and enhance their community development activities through their involvement with the Australian Aid-funded Vanuatu Church Partnership Program (VCPP). ${ }^{8}$ This is modelled on a larger programme that has been operating in Papua New Guinea for a longer period (Clarke 2015). Beginning in Vanuatu in 2009, involvement in this programme has helped to strengthen church administration and the capacity of a range of community leaders, lay and ordained, to undertake larger community development initiatives. Working in formal partnership with Australian-based NGOs, the different member churches in Vanuatu have been able to implement larger, long-term development activities. For example, the Presbyterian Church is working with a community of 400 people on an island off South Malakula to address climate change. This new funding stream has given churches new opportunities to engage with their local communities and initiate interventions that would not have been undertaken in the absence of this funding.

The pressure this places on churches needs to be better understood as they increasingly engage with development funding and activities. Are churches willing to increase their involvement in 'development' activities or is there some resistance to these attempts at partnership, perhaps arising from critiques that such work is a distraction from their core responsibilities and duties? At what point do churches stop being primarily interested in spiritual development and focus instead on material development? Does this focus on the church as an innovative deliverer of aid diminish or change the roles that secular civil society (to the extent that it exists within Vanuatu) plays in development processes, and/or constrain its growth and functioning? Understanding the impact of churches increasingly becoming aid deliverers will provide insights into the absorptive capacity for aid within this small nation.

There is also a question of how churches partner (or accommodate and accept) non-Christian development actors. Cyclone Pam wreaked great devastation on Vanuatu in March 2015. It was the most severe cyclone to impact Vanuatu in recorded history. It affected all parts of the archipelago leaving significant sections of the population without shelter and causing short-term food shortages. Whilst deaths and casualties were minimal, the effect on infrastructure was high with many public buildings, roads, bridges, and markets partially or totally destroyed. For many rural communities the damage to transport infrastructure had a significant impact on their capacity to access markets, education, health care, and other social services. Local and international NGOs responded swiftly 
and generously to the humanitarian needs that resulted. Many of these responding NGOs were FBOs. While many had pre-existing relationships with local communities, a large number of NGOs also began operating within Vanuatu for the first time. This included a number of actors that did not have a specifically Christian identity. One such faith-based organisation was Muslim Aid Australia. Muslim Aid is an Australia-based NGO established in 1989. It responds to both longer term development issues as well as humanitarian emergencies. While it has a presence in over fifty countries around the world, this was the first time Muslim Aid Australia had undertaken any services in Vanuatu. In a country with a total estimated Muslim population of 200 individuals spread across the entire country, and with the first Muslim arriving in Vanuatu only in 1978, how Muslim Aid Australia experienced this unprecedented interreligious encounter in such a mono-religious society is of interest. Muslim Aid initially worked in ten communities in the capital city of Vila, distributing essential food supplies. They then moved to one of the regional provinces, becoming one of the first NGOs to work in Tanna, again delivering essential food supplies to last three to four months.

It remains unclear at this stage whether Muslim Aid Australia intends to undertake longer term development activities within Vanuatu, but the response by local communities to their humanitarian mission is of interest. Was there resistance or awkwardness or suspicion of this aid? Did local communities engage positively with the staff from Muslim Aid Australia or were they advised against too close co-operation by church leaders? Was Muslim Aid Australia considered differently because of their faith base than traditional Christian FBOs or secular NGOs? Understanding how non-Christian FBOs operate in Vanuatu may provide valuable insights for how a wider range of NGOs are able to successfully navigate their involvement in Vanuatu in the future.

\section{How can church responses to humanitarian emergencies be improved?}

Given its low level of development and its geographic location, Vanuatu is one of the world's most disaster-prone countries, at risk from earthquakes, cyclones, drought, floods, sea surge, climate change, and volcanoes (Birkmann et al. 2015). The lack of coping and adaptive capacities within the country, largely as a result of lack of resources, exacerbates this risk. In response, national government disaster response plans include churches and church buildings as places of sanctuary during disasters.

According to the Chair of the Vanuatu Christian Council, 'church buildings are often the strongest buildings in communities. From our Ni-Vanuatu con- 
struction advisors' observations of villages across Vanuatu, almost every single village has a strong church, but not every village has a strong school or village' (Daily Post 2015, 5). Thus, many thousands of Ni-Vanuatu sought refuge and sanctuary in their churches, on the advice of the government, NGOs, and civil society following Cyclone Pam in 2015. More than fifty churches were officially utilised as evacuation centres in the days and weeks following this event (Daily Post 2015).

The ability of the churches to offer sanctuary to those affected is not just confined to material safety; they also provide spiritual support. The power of the cyclone and the damage it wrought also resulted in an emotional toll on many inhabitants across Vanuatu. In recognition of this, the Presbyterian Church quickly brought together its pastors, elders, and PMwU leaders to attend a two-day workshop to provide training on how to provide appropriate psychoemotional support. Yet, questions remain about how qualified and resourced the churches in Vanuatu are to provide effective material and spiritual support. Are they properly embedded in formal disaster planning and response, or just a convenient additional resource to be taken advantage of by government and civil society agencies in times of need? Certainly, there are indications that the inclusion of churches and church buildings in the five-year reconstruction program has been resisted by the Vanuatu Government, which has seen the reconstruction of these facilities as outside of its mandate.

\section{CONCLUSION}

The premise of these seven questions, based on recent in-country fieldwork across a range of sectors, is that authentic engagement with religion in Vanuatu, and in the broader Pacific, is necessary for good development outcomes to be achieved. Christianity in Vanuatu is thus conceived as having Goulet's (1980, 485) 'latent dynamism'. Authentic engagement involves fully appreciating that religion is 'a part' of the development process and not something that is 'apart' from it. Religion is increasingly being acknowledged as having an important role in the success or otherwise of community development initiatives. Until recently, this role has been under appreciated. By seeking to provide wellresearched answers to these seven questions (and undoubtedly there are many others), it is possible to move beyond the approach to religion that has previously characterised the operations of the development sector in the region. Religion is seen by some as essentially personal, but nevertheless it has important social impacts throughout the Pacific region. Religion might constrain certain aspects of modernisation, but it also plays an important role in social support and networking that leverages other opportunities. Religion may be part of a country's 
culture, but in many countries, religion is so overwhelmingly important that it cannot be subsumed under this catch-all and requires specific investigation in its own right. As such, understanding religion provides insights as to how religious belief, practices, and organisations can be potent tools for change in the social, ideological, economic, and political realms. Authentic engagement with religion does not mean abandoning one's own principles or beliefs. It does, however, require an acceptance of the genuineness of others' beliefs as being genuinely held, as well as forfeiting long held stereotypes regarding religion such as on gender, HIV and AIDS, and political structures.

While religion is not a panacea for achieving better development goals - and it can actively work against achieving such goals - excluding religion from consideration within the development process diminishes the possibility that these good outcomes will be achieved. Positive consideration of religion in development is of course happening already, but more is required. It is hoped that future attempts to answer the questions above will enhance this authentic engagement in Vanuatu and result in even better development outcomes than are already been achieved.

NOTES

1 Alfred Deakin Professor Matthew Clarke is Head of the School of Humanities and Social Sciences, Deakin University (Australia). Matthew's research includes aid effectiveness, development in the Pacific, and religion and development.

Email: mclarke@deakin.edu.au

2 See also Jurgensmeyer (2010) for discussion around impact of religion on issues of international security.

3 Thirteen per cent of the population who nominated themselves as 'Other' in the 2009 census did so because their denomination was not one of those listed on the census form, which only included: Presbyterian, Anglican, Catholic, Seventh Day Adventist, Apostolic, Churches of Christ, Assemblies of God, and Neil Thomas Ministries.

4 This paper is concerned with Vanuatu following contact with European missionaries. For a greater appreciation of the long history of Vanuatu before these events, see Bedford and Spriggs (2014).

5 Hilliard (1978) notes negative interactions between early missionaries and argues that conversion to Christianity significantly impacted certain existing belief 
systems. While not dismissing these tensions, this chapter purposely focuses on the positive impact Christian churches have had across the social, political, and economic development of Vanuatu.

6 See Eriksen (2016) for analysis of traditional gender roles on the Vanuatu island of Ambrym in which women in the past - through the marriage system - had greater geographical mobility then men 'and brought Christianity to new villages' (p.262).

7 This is not unusual: for example, within Australia, eighteen per cent of the adult population attend a religious service at least once every month, and women make up a larger percentage of this group, with twenty per cent of women attending monthly against only sixteen per cent of men. On the other hand, men are more likely than women to never attend (fifty-two per cent versus forty-six per cent) (Household Income and Labour Dynamics in Australia 2014). Of interest, younger women (commonly characterised as 'Generation Y') are not more likely than similarly aged younger men to attend religious services, with attendance taking place in equal proportions. Among other generations, it is women who attend more, especially amongst the oldest members of the community.

8 Churches receiving funding the through the VCPP include Presbyterian, Anglican, Seventh-day Adventist, Assemblies of God, Apostolic, and Churches of Christ. The Catholic Church is a not a participating member of the vCPP but does work in close partnership with Caritas.

\section{REFERENCES}

Asia Development Bank. 2005. Asia Economic Outlook 2005. Manilla: Asia Development Bank.

Bedford, Stuart, and Matthew Spriggs. 2014. 'The Archaeology of Vanuatu, 3,00o Years of History across Islands of Ash and Coral. In The Oxford Handbook of Prehistoric Ocean, edited by Ethan Cochrane and Terry Hunt, 1-17. Oxford: Oxford University Press.

Birkmann, Jörn, Matthias Garschagen, Peter Mucke, Almuth Schauber, Thomas Seibert, Torsten Welle, Jakob Rhyner, Stefan Kohler, Thomas Loster, Dirk Reinhard, and Ira Matuschke. 2014. World Risk Report 2014, Bonn: Bündnis Entwicklung Hilft and UNU-EHS. 
Brown, Terry. 2009. 'Reflections on the History of the Theology and Practice of 'Development' (Past and Present in the Anglican Church of Melanesia in Solomon Islands and Vanuatu)'. Unpublished mimeo. Honiara: Church of Melanesia.

Clarke, Matthew. 2011. Development and Religion: Theology and Practice. Cheltenham: Edward Elgar Publishing.

Clarke, Matthew, ed. 2013. Handbook of Research on Development and Research. Cheltenham: Edward Elgar Publishing.

Clarke, Matthew. 2015. 'Innovative Delivery Mechanisms: Australian Aid Partnership with Churches in Papua New Guinea' Journal of International Development 27 (8):1462-1478.

Clarke, Matthew, Simon Feeny, and Lachlan McDonald. 2014. 'Vulnerability to What? Multidimensional Poverty in Melanesia'. In Household Vulnerability and Resilience to Economic Shocks: Findings from Melanesia, edited by Simon Feeny, 83-106. Farnham: Ashgate.

Clarke, Matthew, and Anna Halafoff. 2017. Religion and Development in the AsiaPacific: Sacred Places as Development Spaces. London: Routledge.

Crowley, Terry. 2005. 'Competing Agendas in Indigenous-Language Renewal: Initial Vernacular Education in Vanuatu'. International Journal of the Sociology of Language 172:31-49.

Daily Post. 2015. 'Include Churches in Gov’t Recovery Management Framework: vcC', Daily Post, p. 5, June 3, Vanuatu.

Deneulin, Séverine, with Masooda Bano. 2009. Religion in Development: Rewriting the Secular Script. London: Zed Books.

Douglas, Bronwen. 2002. 'Christian Citizens'. The Contemporary Pacific 14 (1):1-38.

Eriksen, Annelin. 2008. Gender, Christianity and Change in Vanuatu: An Analysis of Social Movements in North Ambrym. Aldershot: Ashgate.

Fountain, Philip, Robin Bush, and R. Michael Feener, eds. 2015. Religion and the Politics of Development. Basingstoke: Palgrave. 
Fox, Jonathan, and Shmeul Sandler, eds. 2006. Religion in World Conflict. London: Routledge.

Goulet, Denis. 1980. 'Development Experts: The One-Eyed Giants'. World Development $8(6-7): 481-489$.

Hilliard, David. 1978. God's Gentlemen: A History of the Melanesian Mission 18491942. Brisbane: University of Queensland Press.

Household Income and Labour Dynamics in Australia (HILDA). 2015. Household Income and Labour Dynamics in Australia Survey: Selected Findings from Waves 1 to 12. Accessed 16 August 2016 from https://www.melbourneinstitute. com/downloads/hilda/Stat_Report/statreport_2015.pdf

Jurgensmeyer, Mark. 2010. 'The Global Rise of Religious Nationalism'. Australian Journal of International Affairs 64 (3):262-273.

Leach, Michael, James Scambary, Matthew Clarke, Simon Feeny, and Heather Wallace. 2013. Attitudes to National Identity in Melanesia and Timor-Leste: A Survey of Future Leaders in Papua New Guinea, Solomon Islands, Vanuatu and Timor-Leste. Oxford: Peter Lang.

Lini, Walter. 1982. 'Lini Pleads for Understanding of the "Melanesian Resistance". Pacific Islands Monthly 53 (4):25-28.

Massam, Katharine. 2014. 'Creating Spaces Between: Women and Mission in Oceania'. In Explorations in Practical Theology: Bridging the Divide Between Faith, Theology and Life: The Church in Oceania, edited by Antony Maher, 123-133. Adelaide: Australian Theological Forum.

Mate, Rekopantswe. 2002. 'Wombs As God's Laboratories: Pentecostal Discourse of Femininity in Zimbabwe'. Africa 72 (4):549-568.

Miles, William. 1998. Bridging Mental Boundaries in a Post-Colonial Microcosm: Identity and Development in Vanuatu. Honolulu: University of Hawai'i Press.

Mitchell, Jean. 2004. "Killing Time” in a Postcolonial Town: Young People and Settlement in Port Vila, Vanuatu'. In Globalization and Culture Change in the Pacific Islands, edited by Victoria Lockwood, 358-376. Upper Saddle River, New Jersey: Pearson Prentice Hall. 
Rees, John. 2011. Religion in International Politics and Development: The World Bank and Faith Institutions. Cheltenham: Edward Elgar.

Regenvanu, Sethy. 2004. Laef Blong Mi: From Village to Nation. Suva: University of South Pacific Press.

Seiple, Robert, and Dennis Hoover, eds. 2004. Religion and Security: The New Nexus in International Relations. Lanham: Rowman and Littlefield.

Singleton, Andrew. 2014. Religion, Culture and Society: A Global Approach. London: Sage.

ter Haar, Gerri, ed. 2011. Religion and Development: Ways of Transforming the World. London: Hurst.

Tomalin, Emma, ed. 2015. The Routledge Handbook of Religions and Global Development. Routledge: London.

Vanuatu National Statistics Office (vNso). 2009. 2009 National Census of Population and Housing. Accessed 8 October 2016 from http://www.vnso.gov.vu/ images/PublicDocuments/Census/2009/2009\%20Census\%20Analytical\%20 Report\%2O-\%20Vol2.pdf

Woodward, Keith. 2014. A Political Memoir of the Anglo-French Condominium of the New Hebrides. Canberra: AnU Press. 